\title{
Analysis of factors affecting sharia compliance levels in sharia banks in Indonesia
}

\author{
Fajar Satriya Segarawasesa \\ Faculty of Economics, Social Sciences and Humanities, Universitas Aisyiyah \\ Yogyakarta, Yogyakarta, Indonesia \\ Corresponding author: fajarsatriyas@unisayogya.ac.id
}

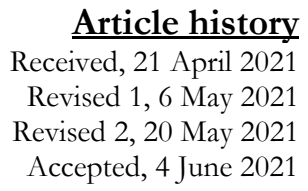

\begin{abstract}
Purpose: This study aims to analyze the factors that influence the level of sharia compliance in sharia banks in Indonesia. In particular, this study examines the effect of liquidity, firm size, Sharia Supervisory Board Size, and Audit Committee on the level of sharia compliance in sharia banks in Indonesia.
\end{abstract}

Methodology: This study uses quantitative methods with secondary data in the form of sharia bank annual reports 2014-2018. The data analysis uses regression test with the help of SPSS software.

Findings: The results of the analysis show that the size of the sharia supervisory board and audit committee has a positive effect on the level of sharia compliance. The findings of this study contribute to the literature on sharia compliance and disclosure in Sharia banking in Indonesia.

Practical implications: This research also has implications for sharia banking, especially in Indonesia, as an evaluation material in improving the quality of financial reports.

Originality: This study uses the sharia compliance index as a measuring tool for the level of compliance of sharia banks which is rarely used by previous studies.

Keywords: Sharia Compliance Index, Liquidity, Company Size, Sharia Supervisory Board Size, Audit Committee.

\section{Cite this article:}

Segarawasesa, F. S. (2021). Analysis of Factors Affecting Sharia Compliance Levels in Sharia Banks in Indonesia. Asian Journal of Islamic Management, 3 (1), 5666. https://doi.org/10.1108/AJIM.vol3.iss1.art6.

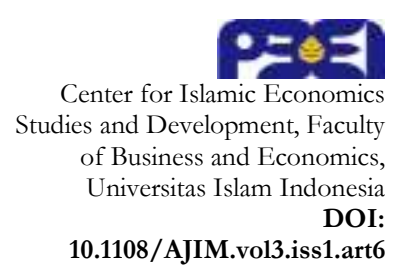

\section{Introduction}

The global financial crisis that hit the world in the 2007-2008 period caused many conventional banks to experience financial difficulties. In Indonesia, sharia banks have successfully overcome this crisis. The exposure to Sharia banking financing, which is more directed to the domestic economy, does not have a high level of integration with the world financial system and does not yet have a high level of transaction sophistication. These two factors have saved sharia banks from the direct impact of the global crisis.

Based on data from the Sharia Banking Statistics, it is stated that the number of Sharia Commercial Banks in 2009 was only three banks with 711 offices (Otoritas Jasa Keuangan, 2020). Meanwhile, until December 2020, the number of sharia banks in existence has more than doubled; 14 banks were established with the number of 2,034 offices which also experienced a significant increase compared to 2009. Generally, all Sharia Commercial Banks, Sharia Business Units, and Sharia Financing Banks have reached 2426 offices. Therefore, it can be concluded that the growth of Sharia banks in Indonesia is relatively fast.

Sharia banks in Indonesia have been regulated by various regulations, including the Law (UU) on Sharia Banking and Banking, regulations issued by Bank Indonesia (BI) regarding Sharia 
Banking, fatwas issued by the National Sharia Board of the Ulama Council. Indonesia (DSN MUI), Sharia Financial Accounting Standards Statement (PSAK) issued by the Sharia Accounting Standards Board, and Indonesian Sharia Banking Accounting Guidelines (PAPSI) issued by BI.

Although the source of Sharia law is based on Al-Quran and Hadith, this does not mean that at this time, sharia law is universally applicable to control and administratively regulate sharia entities, including sharia banks. The absence of a globally applicable sharia accounting standard has the potential to result in different practices and parameters even though the label is the same (Listiana, 2016). The challenge that arises for sharia banking is when banks have to comply with sharia accounting standards and at the same time have to compete with conventional banks that are free and unrestricted. In practice that occurs in the field, these limits are often an obstacle to development.

Previous research by Sellami \& Tahari (2017) about the factors affecting Sharia banks' level of sharia banking compliance, which is AOIFI financial accounting standards, found wide variations in the level of compliance among accounting disclosures standards. It also revealed that compliance is positively related to the listing status, presence of audit committee, bank age, and country of domicile. Another research conducted by El-halaby \& Hussainey (2016) about the determinants of the level of compliance with the AAOIFI (Accounting and Auditing Organization for Sharia Financial Institute) standards by Sharia banks show that company size, company age, internal sharia audit, uncertainty avoidance, and sharia supervisory board governance affect the level of unbelief. Previous research in the context of Sharia banking in Indonesia by Listiana (2016) showed that the level of compliance of Sharia commercial banks in terms of disclosure is higher than the level of compliance with sharia business units. Giant sharia banks are also proven to have a higher sharia compliance index than the smaller ones. Sharia banks audited by the big- 4 accounting firms are also proven to have a higher sharia compliance index than other banks that do not.

In connection with research on the company's level of compliance which the author has evaluated the factors, there are many weaknesses and suggestions given by previous research. For example, in Listiana's (2016) research, the indicators used in measuring the sharia compliance index are limited to 7 categories related to contracts or transactions. Researchers also suggest that different levels of compliance can be measured in terms of disclosure by using variations in contracts and transactions. Moreover, they also recommend using other proxies in measuring the entity's size through financial performance in the form of profitability, liquidity, solvency, and other indicators. Finally, the researchers also suggest that further research could be performed with the influence of certain factors on Sharia banking compliance level by using a regression equation.

Additionally, Demir \& Bahadir (2014) introduced volunteer items to classify mandatory disclosures into discrete groups (e.g. financial and non-financial information), combining other company characteristics (e.g. ownership concentration and institutional ownership), and building a disclosure index based on the value of users of financial information attached to each disclosure item. El-halaby \& Hussainey (2016) also suggested considering other variables such as GDP, corruption index, audit committee, leverage, ownership structure, and also examining compliance levels for other financial institutions. Sellami \& Tahari (2017) stated that further research is expected to use disclosure accounting standards and all accounting standards.

This study combines previous research conducted by Listiana (2016) related to the analysis of the level of compliance of Sharia banks according to sharia regulations by following the advice of previous researchers. The variables that are the focus of the author in this study include Liquidity, Company Size, Sharia Supervisory Board Size, and Audit Committee. This research is expected to contribute to Sharia banking study in Indonesia since research on these factors has not been conducted much. In addition, this study will also analyze the development of the level of sharia compliance in Sharia banking in Indonesia concerning the revision of PSAK 59.

\section{Literature Review and Hypotheses Development}

According to Jensen \& Meckling (1976), agency theory is defined as a contract in which one or more people (principal) order another person (agent) to perform a service on behalf of the principal and 
authorize the agent to make the best decisions for the principal. If both parties have the same goal of maximizing company value, it is believed that the agent will act in a manner consistent with the principal's interests. Agency theory predicts that the separation of the owner (principal) and the manager (agent) can cause corporate managers to take actions that do not maximize shareholder wealth. Managers are believed to like decisions or plans that maximize their well-being at the expense of shareholders. In other words, managers will try to fulfill their own interests regardless of shareholder wealth. In this situation, a conflict of interest between the principal and the agent will occur.

Sharia transactions are based on the paradigm that Allah The Almighty created the universe as a mandate and means of life for all mankind in achieving actual material and spiritual prosperity (al-falab) (Basic Framework for the Preparation and Presentation of Sharia Financial Statements). This fundamental paradigm emphasizes that every human activity has accountability and religious values that place Sharia instruments and morals as parameters of good and bad, right and wrong of business activities. This paradigm will form integrity that helps to shape the character of good corporate governance and good market discipline.

As a part of Sharia entities, Sharia Bank is obliged to provide accountability in the form of adequate disclosure through its required financial reporting according to the applicable Sharia regulations. Adequate disclosure according to applicable Sharia provisions is required in order to provide information to interested parties to minimize the occurrence of information asymmetry.

\section{Liquidity}

Liquidity is the company's ability to meet its short-term obligations. The higher the level of liquidity of a company, the better the company's performance. Companies with a high level of liquidity are usually more likely to get various kinds of support from outside parties such as financial institutions, creditors, and suppliers of raw materials.

Agency theory states that company managers as agents try to fulfill the interests of investors (principals), among others, by increasing company value and maintaining the continuity of company operations by maintaining liquidity so that the company can last a long time. Wallace \& Naser (1995) argued that companies with high liquidity tend to disclose more information to show the capital market that they have the resources to meet their short-term goals. In addition, companies with higher liquidity are expected to disclose more information temporarily to demonstrate their ability to maintain their earnings forecasts. Roziani \& Sofie (2010) conducted previous research related to this variable, which stated that liquidity has a positive effect on social disclosure in Sharia banks. So from this explanation, the hypothesis of this study is as follows:

H1: Liquidity has a positive effect on the level of sharia compliance in Sharia banks in Indonesia.

\section{Company Size}

Company size is the total assets owned by the bank, where the total assets can be seen in the total assets contained in the bank's financial statements on the balance sheet. Company size influences the profits obtained at a bank, where the larger the size of a bank, the greater the profit earned by the bank. Firm size is a crucial determinant of the choice of disclosure and accounting policies (A. Rahman, Perera, \& Ganesh, 2002). Large companies also face higher demands for information from customers, analysts, suppliers, and the general public (Cooke, 1989). Larger firms tend to have higher levels of analysts than smaller firms, and therefore the demand for transient information also tends to be more significant.

Agency theory says that larger firms have higher agency costs because they have many shareholders and contract more with smaller firms (Jensen \& Meckling, 1976). Previous research that supports this variable includes El-halaby \& Hussainey (2015); Syahierah \& Larasati (2019) stated that company size is positively related to CSR disclosure. Listiana (2016) also stated that Sharia banks with a large size have a high sharia compliance index. Ajili \& Bouri (2016) certified that compliance with IFRS / AAOIFI disclosure requirements is higher for larger banks. El-halaby \& Hussainey (2016) also agreed that company size is positively related to disclosure compliance. Rahman \& Hamdan (2017) 
gave the same result that the company's size is positively related to the level of compliance. Al-Sartawi Musleh \& Reyad (2018) also found that company size positively affects online financial statement disclosure. Hence, from this explanation, the hypothesis of this study is as follows:

H2: Company size has a positive effect on the level of sharia compliance in Sharia banks in Indonesia.

\section{Sharia Supervisory Board Size}

Sharia bank governance is different from conventional bank governance because its main objective is to ensure compliance of bank operations and products under sharia regulations. In Sharia banks, the sharia supervisory board acts as an internal and independent governance structure that encourages transparency. Therefore, its characteristics affect the level of disclosure in Sharia banks. The number of members of the sharia supervisory board that is usually present in Sharia banks is between three and five members based on the AAOIFI Governance Standard No.7. According to Chen \& Jaggi (2000), a larger board size decreases the likelihood of information asymmetry. Furthermore, agency theory predicts that larger boards combine diverse expertise, resulting in a more effective monitoring role for the board. In addition, a higher number of board members reduces uncertainty and lack of information.

Board size is likely to affect its ability to control and review all transactions to ensure its operation. With more members, the collective knowledge and experience of the sharia supervisory board will increase, leading to greater disclosure. Previous research related to this variable has been conducted by El-halaby \& Hussainey (2016); Srairi (2018) showed that the size of the sharia supervisory board affects disclosure compliance. Other research by Utami (2016) shows that the size of the sharia supervisory board has a positive effect on ISR disclosure. Therefore from this explanation, the hypothesis of this study is as follows:

H3: The size of the Sharia Supervisory Board has a positive effect on the level of sharia compliance in Sharia banks in Indonesia.

\section{Audit Committee}

Audit committees are a monitoring mechanism established voluntarily in high agency costs to improve the quality of information flow between principals and agents (Bradbury, 1990). Menon \& Williams (1994) argued that audit committees with fewer than three members were less likely to be effective. However, Anderson et al. (2004) stated that large audit committees can be more effective because there are more members with various expertise to enable them to perform a variety of tasks related to monitoring financial reporting practices.

Agency theory predicts that audit committees should lower agency costs, primarily if they are composed predominantly of non-executive directors, following international best practice (Samaha et al., 2012). The presence of an audit committee has a positive effect on disclosure compliance. The audit committee is generally considered an essential component of a company's overall corporate governance structure, especially with the responsibility to ensure the integrity of the company's financial statements (Sellami \& Tahari, 2017).

Previous research that supports this variable is Samaha et al. (2012) showed that the audit committee affects the level of disclosure. Glaum et al. (2013) also showed that the audit committee has an effect on the level of compliance with IFRS disclosures. Said et al. (2017) also stated that the audit committee affects CSR disclosure. Sellami \& Tahari (2017) showed the same result that the audit committee has a positive effect on the level of compliance with AAOIFI disclosures. Elgattani (2020) also showed the same result that the audit committee positively affects the disclosure of AAOIFI Governance in Sharia banking. Thus, from this explanation, the hypothesis of this study is as follows:

H4: The Audit Committee has a positive effect on the level of sharia compliance in Sharia banks in Indonesia.

Based on the development of the hypothesis, Figure 1 presents the research model. 


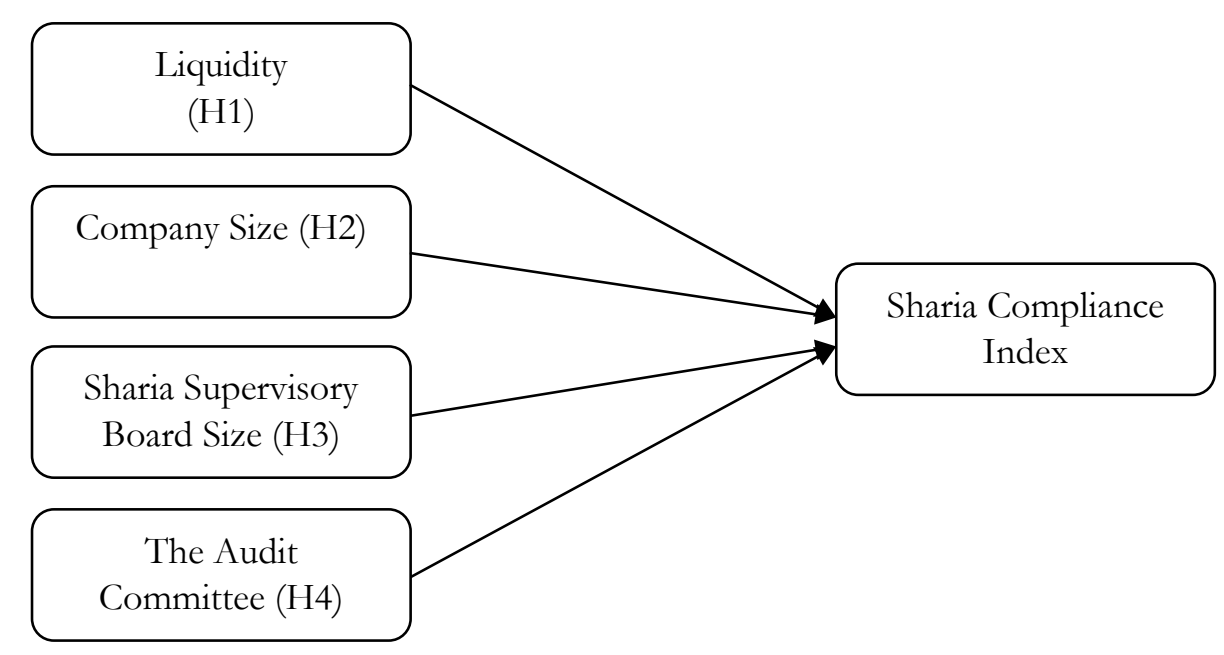

Figure 1. Research Model

\section{Methodology}

\section{Population and Sample}

This research is quantitative using secondary data. This study uses the documentation method in data collection. It is a media intermediary data collection method related to the subject matter.

The population in this study is Sharia Commercial Banks in Indonesia. This study uses a purposive sampling method with the criteria of Sharia banks that publish their annual reports on the websites of each Sharia bank, presenting annual report data for the 2014-2018 period.

\section{Measurements}

The dependent variable in the study is the Sharia compliance index. The sharia compliance index in this study is measured by reviewing the index from previous research conducted by (Listiana, 2016). This Sharia compliance index refers to the 2013 PAPSI, Sharia PSAK, PBI, and also the applicable Sharia Banking Law. The researcher adds the istishna contract with the expectation that the level of disclosure obtained will be better. Each indicator is assessed on a dummy basis, namely one if the indicator is applicable and implemented in the relevant Sharia bank and 0 if the indicator is not implemented. Table 1 presents the details of the sharia compliance index used in this study.

Table 1. Sharia Compliance Index

\begin{tabular}{ll}
\hline No. & Category \\
\hline 1 & Disclosure of Supervisory Board Shariah \\
2a & Disclosure of Mudharabah accounting policies and methods \\
2b & Disclosure of details on the financing of the Mudharabah contract \\
2c & Disclosure of temporary syirkah funds for the Mudharabah contract \\
3a & Disclosure of Murabaha accounting policies and methods \\
3b & Disclosure of details on Murabahah contract financing \\
4a & Disclosure of Musharaka accounting policies and methods \\
4b & Disclosure of details on the financing of the Musyarakah contract \\
5a & Disclosure of Ijarah accounting method policies \\
5b & Disclosure of details of the Ijarah lease agreement \\
6a & Qardh's disclosure of accounting policies and methods \\
6b & Disclosure of details of the Qardh loan agreement \\
7 & Disclosure of Zakat \\
$8 \mathrm{a}$ & Istishna's disclosure of accounting policies and methods \\
8b & Disclosure of details on Istishna contract financing \\
\hline
\end{tabular}


This study uses 80 indicators of the sharia compliance index, which are broadly divided into eight sections. The eight sections are the disclosure of the DPS (a special organ whose existence is required in Sharia banking) as well as various transaction contracts generally performed by Sharia banks, including mudharabah, musyarakah, istishna financing contracts, murabahah, istishna trade contracts, ijarah leases, borrowing contracts in the form of qardh, customer deposits in the form of temporary syirkah funds with a mudharabah profit sharing contract, and zakat activities. In addition, each transaction contract is divided into two parts: an assessment of the disclosure policies and accounting methods used as well as assessing the breakdown of balances and percentages.

The independent variables' measurements in this study were modified from previous research and adjusted to the context of this study. The liquidity variable is measured by the Financing to Deposit Ratio (FDR) indicator modifying the research Roziani \& Sofie (2010). Company size is measured by the Log Total assets adopted from the study El-halaby \& Hussainey (2016). A dummy variable measures the size of Sharia Supervisory Board with a value of 1 for the number of DPS members of more than three and a value of 0 for the number of DPS members less than 3 which was also adopted from the research of Ajili \& Bouri (2018) and for the audit committee variable measured by $\sum$ the audit committee that modified the research of Sellami \& Tahari (2017).

\section{Data Analysis Technique}

This study uses data analysis methods using SPSS software to test the relationship between interconnected variables run on computer media. Data analysis using SPSS includes testing the regression model. Before conducting multiple linear regression analyses, a descriptive statistical test and a classical assumption test are first conducted.

This study used descriptive statistics as a way to describe the data that has been collected as is without intending to apply to general conclusions or generalizations. The classic assumption test is used to examine whether the data meets the basic assumptions. It is important to avoid biased estimates. Tests performed in this research are normality test, multicollinearity test, and heteroscedasticity test.

\section{Results and Discussion}

Based on the sampling criteria, 11 research objects that met the criteria were obtained. Hence the total observations from 2014-2018 are 55 samples. Table 2 presents a list of samples used in this study.

Table 2. Sharia Commercial Bank Sample 2014-2018

\begin{tabular}{ll}
\hline No. & Name Sharia Commercial Bank \\
\hline 1. & PT. Bank Syariah Mandiri \\
2. & PT. Bank BRI Syariah \\
3. & PT. Bank BNI Syariah \\
4. & PT. Bank Muamalat Indonesia \\
5. & PT. Bank Panin Dubai Syariah \\
6. & PT. Bank Mega Syariah \\
7. & PT. Bank Syariah Bukopin \\
8. & PT. Bank BCA Syariah \\
9. & PT. Bank Jabar Banten Syariah \\
10. & PT. Bank Victoria Syariah \\
11. & PT. Bank Maybank Syariah \\
\hline Source: Result of Research, 2020
\end{tabular}

The results of the descriptive analysis of the variables used in this study are shown in table 3. Based on table 3, it is found that the variable sharia compliance index (SCI) has a minimum value of 0.4625 , a maximum value of 0.9000 , an average value of 0.692227 , and a standard deviation value of 0.1269657 . The liquidity variable (FDR) has a minimum value of 0.0000 , a maximum value 
of 1.5780 , an average value of 0.889927 , and a standard deviation of 0.1822035 . Company Size (SIZE) has a minimum value of 5.82, a maximum value of 13.85 , an average value of 9,8329, and a standard deviation of 2,37636. The variable size of the Sharia supervisory board (SSB) has a minimum value of 0 , a maximum value of 1 , an average value of 0.33 , and a standard deviation of 0.474 . The audit committee variable (KA) has a minimum value of 2 , a maximum value of 7 , an average value of 3.82 , and a standard deviation of 1.172 .

Table 3. Descriptive Analysis of Research Variable

\begin{tabular}{llllll}
\hline & _SCI & FDR & SIZE & SSB & KA \\
\hline Mean & 0.692227 & 0.889927 & 9.8329 & 0.33 & 3.82 \\
Maximum & 0.9000 & 1.5780 & 13.85 & 1 & 7 \\
Minimum & 0.4625 & 0.0000 & 5.82 & 0 & 2 \\
Std. Dev. & 0.1269657 & 0.1822035 & 2.37636 & 0.474 & 1.172 \\
N & 55 & 55 & 55 & 55 & 55 \\
\hline
\end{tabular}

Source: Result of Research, 2020

Table 4. Normality Test

\begin{tabular}{lcl}
\hline & Monte Carlo Sig (2-tailed) & Result \\
\hline Residual & 0,108 & Normal \\
\hline Source: Result of Research, 2020 &
\end{tabular}

The Kolmogorov Smirnov test undertakes the normality test, provided that if the significant level is $>0.05$, then the distribution is normal. On the other hand, if the significant level is $<0.05$, the distribution is not normal. Based on Table 4, it can be seen that the Monte Carlo Sig (2-tailed) value is 0.108 . It shows that the significance value is greater than the $\alpha$ value $(0.108>$ 0.05). It can be concluded that the residual data is normally distributed and can continue to the next classical assumption test.

Multicollinearity test is used to test whether the regression model found a correlation between independent variables (independent). A good regression model should not have a correlation between the independent variables. Multicollinearity testing was carried out using a tolerance value $<0.10$ and the variance inflaction factor (VIF) with the criteria, if the tolerance value was $>0.10$ and VIF $<10$, there was no multicollinearity. Table 5 shows the test results that the variables FDR, SIZE, SSB, and KA have a tolerance value of more than 0.10 and a VIF value of less than 0.10. Based on the test results, it can be decided that the four independent variables in this study do not occur multicollinearity so that the regression model can be used in this study.

Table 5. Multicollinearity Test

\begin{tabular}{llll}
\hline Variable & Tolerance & VIF & Result \\
\hline FDR & 0,946 & 1,057 & There was no multicollinearity \\
SIZE & 0,878 & 1,139 & There was no multicollinearity \\
SSB & 0,833 & 1,201 & There was no multicollinearity \\
KA & 0,721 & 1,388 & There was no multicollinearity \\
\hline
\end{tabular}

Source: Result of Research, 2020

The heteroscedasticity test aims to test whether there is an inequality of variants and residuals in the regression model in the regression model from one observation to another. A good regression model is homoscedasticity or heteroscedasticity that does not occur. Glejser test was applied to test the presence or absence of heteroscedasticity. If the significant t value is greater than the significant value 0.05 , heteroscedasticity does not occur. Table 6 shows the test results that the significance of the four independent variables is more than 0.05. Based on the test results, it can be concluded that there is no heteroscedasticity of the four independent variables in this study. 
Table 6. Heteroscedasticity Test

\begin{tabular}{lll}
\hline Variable & Significancy & Result \\
\hline FDR & 0,203 & There was no heteroscedasticity \\
SIZE & 0,274 & There was no heteroscedasticity \\
SSB & 0,052 & There was no heteroscedasticity \\
KA & 0,151 & There was no heteroscedasticity \\
\hline
\end{tabular}

Source: Result of Research, 2020

The autocorrelation test aims to determine whether there is a correlation between the residuals in observation and the observations of others. Durbin-Watson test was used to test whether there is a correlation or not. If the Durbin Watson (DW) value is between -2 and 2, then autocorrelation does not occur. Based on table 7 , showing the results of testing the DW value (1.485) between -2 and 2, it can be concluded that there is no autocorrelation.

Table 7. Autocorrelation Test

\begin{tabular}{ccc}
\hline $\begin{array}{c}\text { Durbin Watson } \\
\text { Value }\end{array}$ & $\begin{array}{c}\text { Durbin Lower } \\
\text { Value }\end{array}$ & $\begin{array}{c}\text { Durbin Upper } \\
\text { Value }\end{array}$ \\
\hline 1.485 & 1.414 & 1.724 \\
\hline
\end{tabular}

Source: Result of Research, 2020

Table 8 is the result of the regression test for the level of sharia compliance involving FDR, SIZE, SSB, and KA. If the probability value $>0.05$, then Ho is rejected, and vice versa; if the probability value $<0.05$, then $\mathrm{Ha}$ is accepted.

Table 8. Multiple Regression Test Result

\begin{tabular}{llll}
\hline Variable & Std. Error & Coefficients & Sig. \\
\hline FDR & 0.128 & -0.127 & 0.270 \\
SIZE & 0.079 & -0.052 & 0.662 \\
SSB & 0.006 & 0.261 & 0.036 \\
KA & 0.046 & 0.424 & 0.002 \\
\hline
\end{tabular}

Source: Result of Research, 2020

Based on the results of the regression test above, it can be seen in table 8. Liquidity (FDR) has no effect on the level of sharia compliance with a sig value of $0.270>0.05$. It means that high and low liquidity does not affect the level of Sharia compliance. Banks will continue to provide more information in their annual reports to assure creditors that their interests are protected. The results of this study are inconsistent with agency theory. These results support previous research conducted by Elgattani (2020) that liquidity does not positively affect the disclosure of AAOIFI Governance in Sharia banking. In this study, it can be concluded that the first hypothesis, which states that liquidity has a positive effect on the level of sharia compliance of Sharia banks, is not supported.

Company Size (SIZE) does not affect the level of sharia compliance. It is proven by the regression results of the sig value $0.662>0.05$, meaning that the size and size of a company do not affect the level of Sharia compliance. Banks will continue to provide more information in their annual reports. This result is inconsistent with agency theory. The results of this study are in line with previous research conducted by Glaum et al. (2013), which stated that company size has no effect on compliance. Demir \& Bahadir (2014) also stated that company size has no effect on the level of compliance with IFRS disclosures. Another study by Juhmani (2017) implied that company size has no effect on the level of compliance of company disclosures in Bahrain to IFRS. Sellami \& Tahari (2017) also provided the same result that the size of Sharia banks has no effect on compliance with accounting standards. Elgattani (2020); Mnif (2020) also found that 
company size does not positively affect the disclosure of AAOIFI Governance in Sharia banking. In this study, it can be concluded that the second hypothesis, which states that company size has a positive effect on the level of Sharia compliance of Sharia banks, is not supported.

The Sharia Supervisory Board (SSB) size has a positive effect on the level of sharia compliance. This is supported by the regression results with a sig value of $0.036<0.05$ and a positive coefficient of 0.261 . These results support previous research conducted by El-halaby \& Hussainey (2016); Srairi (2018) showed that the size of the sharia supervisory board affects disclosure compliance. The results of this study provide empirical evidence that the existence of a sharia supervisory board is an important variable, which affects the level of sharia compliance in Sharia banks. Mollah \& Zaman (2015) also stated that the Sharia supervisory board has a positive impact on the performance of Sharia banks when they carry out a supervisory role. The results of this study are in line with agency theory. Agency theory suggests that a larger board can combine a wide range of expertise resulting in a more effective board role in monitoring. In addition, a higher number of board members reduces uncertainty and lack of information. With more members, the collective knowledge and experience of the sharia supervisory board will increase, leading to greater disclosure. In this study, it can be concluded that the third hypothesis, which states that the size of the sharia supervisory board has a positive effect on the level of sharia compliance of Sharia banks, is supported.

Lastly, the Audit Committee (KA) has a significant effect on the level of sharia compliance of Sharia banks. It is proven by the regression results of the sig value $0.0002<0.05$ and a positive coefficient of 0.424 . This result is in line with previous research conducted by Glaum et al. (2013), Samaha et al. (2012), Sellami \& Tahari (2017), and Elgattani (2020). The results of this study provide empirical evidence that the existence of an audit committee is an important variable affecting the level of sharia compliance in Sharia banks. The results of this study are in line with agency theory. The audit committee is a monitoring mechanism formed voluntarily when agency costs are high to improve the quality of information between the principal and the agent. The existence of an audit committee is an important part of the decision control system used by the board of directors in monitoring internal control. The audit committee is assigned to follow up and evaluate the Sharia internal audit work results whether the internal audit findings are following Sharia principles. The audit committee is responsible professionally and independently without interference from any party that is not in accordance with the legislation. The existence of the Audit Committee encourages the creation of sound practices in financial reporting, risk management, internal control, and good business ethics. In this study, it can be concluded that the fourth hypothesis, which states that the audit committee has a positive effect on the level of Sharia compliance of Sharia banks, is supported.

\section{Conclusion}

This study examines the effect of liquidity, company size, Sharia supervisory board size, and audit committee on the level of Sharia compliance in Sharia banks in Indonesia. The results show that the size of the Sharia supervisory board and audit committee has a positive effect on the level of Sharia compliance. From these findings, this study has implications for Sharia banks as a reference in evaluating their sharia compliance. The Indonesian Institute of Accountants can be used as a reference in the preparation of PSAK 59 concerning Sharia Banking Accounting. Stakeholders can consider and assess the performance of Sharia banks, especially those related to the compliance of Sharia banks with Sharia principles. Researchers feel that this research is still not perfect, and there are still limitations, such as the limited time period between 2014-2018 and only conducted at 11 Sharia Commercial Banks. Therefore, it is expected that further research can perform research over a wider period, research not only on Sharia commercial banks but also on other Sharia financial institutions such as zakat institution, BMT, BPRS, Takaful, and Waqf institution. 


\section{References}

Ajili, H., \& Bouri, A. (2016). Comparative study between IFRS and AAOIFI disclosure compliance: evidence from Islamic banks in Gulf Co- Operation Council countries. Journal of Financial Reporting and Accounting. https://doi.org/10.1108/JFRA-03-2016-0023

Ajili, H., \& Bouri, A. (2018). Corporate governance quality of Islamic banks: measurement and effect on financial performance. International Journal of Islamic and Middle Eastern Finance and Management, 11(3), 470-487. https://doi.org/10.1108/IMEFM-05-2017-0131

Al-Sartawi Musleh, A., \& Reyad, S. (2018). Signaling theory and the determinants of online financial disclosure. Journal of Economic and Administrative Sciences. https://doi.org/10.1108/JEAS-102017-0103

Anderson, R. C., Mansi, S. A., \& Reeb, D. M. (2004). Board characteristics, accounting report integrity, and the cost of debt. Journal of Accounting and Economics, 37(3), 315-342. https://doi.org/10.1016/j.jacceco.2004.01.004

Bradbury, M. E. (1990). The incentives for voluntary audit committee formation. Journal of Accounting and Public Policy, 9(1), 19-36. https://doi.org/10.1016/0278-4254(90)90019-V

Chen, C. J. P., \& Jaggi, B. (2000). Association between independent non-executive directors, family control and financial disclosures in Hong Kong. Journal of Accounting and Public Policy, 19(45), 285-310. https://doi.org/10.1016/S0278-4254(00)00015-6

Cooke, T. E. (1989). Voluntary Corporate Disclosure by Swedish Companies. Journal of International Financial Management \& Accounting, 1(2), 171-195. https://doi.org/10.1111/j.1467646X.1989.tb00009.x

Demir, V., \& Bahadir, O. (2014). Compliance with International Financial Reporting Standards by Listed Companies in Ghana. International Journal of Business and Management, 9(10), 4-34. https://doi.org/10.5539/ijbm.v9n10p87

El-halaby, S., \& Hussainey, K. (2015). The Determinants of Social Accountability Disclosure $\square$ : Evidence from Islamic Banks around the World. International Journal of Business, 1-29.

El-halaby, S., \& Hussainey, K. (2016). Determinants of Compliance with AAOIFI Standards by Islamic Banks. International Journal of Islamic and Middle Eastern Finance and Management, 9(1). https://doi.org/10.1108/IMEFM-06-2015-0074

Elgattani, T., \& Hussainey, K. (2020). The determinants of AAOIFI governance disclosure in Islamic banks. Journal of Financial Reporting and Accounting, 18(1), 1-18. https://doi.org/10.1108/JFRA-03-2019-0040

Glaum, M., Schmidt, P., Street, D. L., \& Vogel, S. (2013). Compliance with IFRS 3-and IAS 36required disclosures across 17 European countries: Company-and country-level determinants. Accounting and Business Research, 43(3), 163-204. https://doi.org/10.1080/00014788.2012.711131

Jensen, M. C., \& Meckling, W. H. (1976). Theory of the firm: Managerial behavior, agency costs and ownership structure. Journal of Financial Economics, 3(4), 305-360. https://doi.org/10.1016/0304-405X(76)90026-X

Juhmani, O. (2017). Corporate governance and the level of Bahraini corporate compliance with IFRS disclosure. Journal of Applied Accounting Research, 18(1), 22-41. https://doi.org/10.1108/JAAR-05-2015-0045

Listiana, L. (2016). Analisis tingkat kepatuhan perbankan syariah terhadap pengungkapan menurut ketentuan syariah $=$ Syariah compliance analysis on disclosure of islamic banking according to syariah compliance guidelines. Tesis Universitas Indonesia. 
Menon, K., \& Williams, J. D. (1994). The use of audit committees for monitoring. Journal of Accounting and Public Policy, 13(2), 121-139. https://doi.org/10.1016/0278-4254(94)900167

Mnif, Y., \& Tahari, M. (2020). The e ff ect of Islamic banks' speci fi c corporate governance mechanisms on compliance with AAOIFI governance standards. Journal of Islamic Accounting and Business Research, (2011). https://doi.org/10.1108/JIABR-11-2018-0188

Mollah, S., \& Zaman, M. (2015). Shari'ah supervision, corporate governance and performance: Conventional vs. Islamic banks. Journal of Banking and Finance, 58, 418-435. https://doi.org/10.1016/j.jbankfin.2015.04.030

Otoritas Jasa Keuangan. (2020). SPS Perbankan Syariah 2020.

Rahman, A. A., \& Hamdan, M. D. (2017). The extent of compliance with FRS 101 standard: Malaysian evidence. Journal of Applied Accounting Research, 18(1). https://doi.org/http://dx.doi.org/10.1108/MRR-09-2015-0216

Rahman, A., Perera, H., \& Ganesh, S. (2002). Accounting practice harmony, accounting regulation and firm characteristics. Abacus, 38(1), 46-77. https://doi.org/10.1111/1467-6281.00097

Roziani, E. A., \& Sofie. (2010). Analisis Faktor-Faktor Yang Mempengaruhi Tingkat Pengungkapan Sosial Dalam Laporan Tahunan Bank Konvensional Dan Bank Syariah Di Indonesia. Islamic Finance \& Business Review, 5(1), 54-75. https://dx.doi.org/10.30993/tifbr.v5i1.41

Said, R., Joseph, C., \& Sidek, N. Z. M. (2017). Corporate Governance and Corporate Social Responsibility (CSR) Disclosure: The Moderating Role of Cultural Values, 189-206. https://doi.org/10.1108/S2043-052320170000012013

Samaha, K., Dahawy, K., Hussainey, K., \& Stapleton, P. (2012). The extent of corporate governance disclosure and its determinants in a developing market: The case of Egypt. Advances in Accounting, 28(1), 168-178. https://doi.org/10.1016/j.adiac.2011.12.001

Sellami, Y. M., \& Tahari, M. (2017). Factors influencing compliance level with AAOIFI financial accounting standards by Islamic banks. Journal of Applied Accounting Research, 18(1), 137-159. https://doi.org/10.1108/JAAR-01-2015-0005

Srairi, S. (2018). Determinants of Corporate Risk Disclosure Practice: The Case of Islamic Banks in Gulf Cooperation Council Region. The Journal of Muamalat and Islamic Finance Research, 15(1), 16-38. https://doi.org/10.33102/jmifr.v15i1.99

Syahierah, R., \& Larasati, A. (2019). Does company size and profitability affect corporate social responsibility disclosure? Asian Journal of Islamic Management (AJIM), 1(1), 38-50. https://doi.org/10.20885/ajim.vol1.iss1.art4

Utami, M. (2016). Pengaruh Good Corporate Governance (GCG) Terhadap Pengungkapan Islamic Social Reporting (ISR) Pada Perbankan Syariah di Indonesia. JABE Jurnal Akuntansi, Bisnis Dan Ekonomi), 1-18.

Wallace, R. S. O., \& Naser, K. (1995). Firm-specific determinants of the comprehensiveness of mandatory disclosure in the corporate annual reports of firms listed on the stock exchange of Hong Kong. Journal of Accounting and Public Policy, 14(4), 311-368. https://doi.org/10.1016/0278-4254(95)00042-9 